\title{
Local Election of Nepal 2017: An Overview of Gender Inclusion Prospective
}

\author{
Dipendra Bikram Sijapati (M. Phil.)*
}

\begin{abstract}
Gender refers to the socially constituted relations between men and women. It focuses on power relations, roles and challenges along with the existing women's subordination in the society. Gender Inclusiveness is additional diverse activity and process of local governments, local institutions like Ward, Rural Municipality, District Coordination Committee and Municipality with self-reliant local governance and sustainable and effective service providing agencies. This article based on the objective to highlight the existing variation of women's inclusion in local governments among developed and developing countries. It analyses the provisions regarding inclusion addressed in the federal Constitution of Nepal in local elections. This paper widely covers concept, definition, theories, practice, situation, laws, policies and program at all levels. The paper is based on secondary sources of information, data published by Election Commission 2017, in Nepal. The raw data are analysed using the Excel spread program on computer and are calculated in frequency distribution and percentage to make its meaningful analysis. Data are carefully analysed and interpreted for generalization. The gender inclusion in local government is gradually increasing. As in national election 2017, the female elected members in local government are almost 40 percent in the districts of Nepal and the data is more than allocated (33\%) by the Constitution of Nepal 2015 and election manifestos of different political parties. All the acts, policies and constitutions also emphasized the gender inclusion in all sector of Nepalese government.
\end{abstract}

Key words: Gender inclusion, local government, policy, situation \& theory.

\section{Introduction}

Gender refers to the socially constituted relations between men and women. It focuses on power relations and roles and challenges among the existing women's subordination in the society. Gender refers to the socially constructed status, power, roles, responsibility and capacity of men and women. It refers to the rules, norms, customs and practices

*Mr. Sijapati is a Lecturer at the Department of Population Studies, Patan Multiple Campus, TU, Lalitpur, Nepal. Email:sijapatidipendra@gmail.com 
by which biological differences between males and females are translated into socially constructed differences between men and women and boys and girls. In Nepal, women face unequal power relations and gender-based barriers due to a patriarchal society.

\section{Social Inclusion}

The removal of institutional barriers and the enhancement of incentives to increase access by diverse individuals and groups to development opportunities. This requires changes in policies, rules, and social practices and shifts in people's perspectives and behaviour toward excluded groups.

Inclusive democracy build on the principle that political power is dispersed and shared in a variety of ways to protect minorities and to ensure participation and freedom of expression for all citizens (UNDP, 2000). Inclusive democracy emphasizes the quality of representation by striving for consensus and inclusion, not the brute electoral force of the majority. An inclusive democracy also appreciates the need to promote civil society organization. Human Development Report 2000, has emphasized the inclusive democracy to all the people without any discrimination on the basis of gender, race, caste, religion and especially women can take part in any decision making process even in local government (UNDP, 2000).

The Pre-World War II period saw flourishing movements of various forms of feminism; however, the nexus between (economic) development and women was not clearly articulated until the second half of the 20th century. Women first came into focus in development as objects of welfare policies, including those focused on birth control, nutrition, and pregnancy (Moser \& Carolne, 1995). "In 1962, the UN General Assembly asked the Commission on the Status of Women to prepare a report on the role of women in development. Ester Boserup's path breaking study on Women's Role in Economic Development was published in 1970. These events marked.

Monumental moments in developing the liberal paradigm of women in development, and the welfares' approach still remains dominant in development practice today. This article reviews the dominant liberal approaches, including women in development (WID), women and development (WAD), gender and development (GAD) and neoliberal frameworks There is significant overlap among these approaches (for example, WID can be seen as an early version of the neoliberal framework). GAD is most concerned with equity and empowerment (Boserup. E, 2011). Social scientists explain above different matter but in context of Nepal, Nepalese society was heterogeneous and diversify settlement in all provinces in local areas and the important part of Nepalese gender development slogans " Men and women are considered 
as two wheels of cart" but in practice women have been backward". In demographic situation, the female population of Nepal is 1,36,45,463 in total population 2,64,94,504 (CBS, 2011). The socio-economic and political conditions of this half section of population are miserable. Women's participation in power and access to resources and opportunity is very negligible. They are bounded in household works and subsistence activities. Their contribution in economy is underestimated though they have significant contribution in household economy. Fifty percent women constitute the total population around the world yet their participation in decisions making at various levels is negligible. Men monopolize the political space all over the world. In many countries women have played a very important role in the independent movements for democracy but their participation in various spheres of public life has continued to remain miserable in comparison to their male counter parts. Political participation of women in South Asia is not very encouraging. Although special provisions have been made in many counties in this region to increase women's political participation, their percentage at higher level has not been increased.

Exclusion and inequality come at a high cost without the equal participation of all people, including individuals at risk of exclusion; society has less an opportunity to reach its full potential, both in terms of its economy and its level of governance. In other words, gender equality and social inclusion are social goods, more than simply being something we intrinsically feel is 'the right thing to do'. In fact, not only inclusion has a positive impact on those who are excluded, it also positively impacts the economy and governance for the benefit of the whole society (UN, 2013).

Gender Inclusiveness is additional dimensional activity and process of local governments in the Ward, VDC (Gaunpalika), DCC (District coordination committee) and Municipality (LGs) with self-reliant local governance and sustainable development and effective service providing to local government.

\section{Objectives}

The main objective of the study is to highlight the existing variations of gender participation at local governments of Nepal. The specific objectives of the study is to analyse some of the constitutional provision on the matter of inclusion in local elections in Nepal.

\section{Methodology}

The essential data and information are mostly collected from secondary sources. Nepal Election Commission-2017 and other related published information like policies, acts and programmes, books, journals and reports are basically used in this paper. The raw data were provided by the Election Commission of Nepal. Later, the acquired data were 
entered into the Ms. Excel program. Finally, those data were calculated and tabulated by SPSS program in computer and data were presented by frequency distribution and crosstabulation for meaningful analysis.

\section{Discussion and Results}

\section{Concepts of Gender Inclusion in Local Government}

UNESCO (2017) defines the Gender Inclusion as "Gender equality and empowerment of women as well as the active participation of women in political, economic, social and cultural life should be promoted. For women to be able to fully exercise their human rights, gender perspectives have to be mainstreamed in all inclusive urban policies."

The gender equality, equality between men and women, entails the concept that all human beings, both men and women, are free to develop their personal abilities and make choices without the limitations set by stereotypes, rigid gender roles and prejudices. Gender equality means that the different behavior, aspirations and needs of women and men are considered, valued and favored equally. It does not mean that women and men have to become the same, but that their rights, responsibilities and opportunities will not depend on whether they are born male or female. Gender equity means fairness of treatment for women and men, according to their respective needs. This may include equal treatment or treatment that is different but which is considered equivalent in terms of rights, benefits, obligations and opportunities (ILO, 2000).

UNICEF (2011), gender equality means that women and men, and girls and boys, enjoy the same rights, resources, opportunities and protections. It does not require that girls and boys, or women and men, be the same, or that they be treated exactly alike.

Table-1: Policy on gender inclusion in polity

\begin{tabular}{|l|l|}
\hline \multicolumn{1}{|c|}{ Constitutions/Laws/Policies/Acts } & \multicolumn{1}{|c|}{ Policy Emphasized in Gender Inclusion } \\
\hline $\begin{array}{l}\text { Beijing General Assembly (13 October } \\
1997\end{array}$ & $\begin{array}{l}\text { Emphasized for gender equality and representation of female in local } \\
\text { election. } \\
\text { The promoted the participation of all women in local decision-making. }\end{array}$ \\
\hline $\begin{array}{l}\text { UN Millennium Declaration (2000- } \\
\text { 2015) }\end{array}$ & $\begin{array}{l}\text { Out of 8 goals, 3 } 3^{\text {rd }} \text { goal was "Promoted Gender Equality and Empower } \\
\text { Women. }\end{array}$ \\
\hline $\begin{array}{l}\text { The Human Development Report } \\
(1995)\end{array}$ & $\begin{array}{l}\text { Concluded that, each and every country required to promote equality and } \\
\text { women should have access at least 30 percent decision-making positions. }\end{array}$ \\
\hline Nepal & \\
\hline
\end{tabular}

Sources: Based on Literature Reviewed, 2018 
Table-2: Political parties and their commitment in election manifestos, 2017.

\begin{tabular}{|l|l|}
\hline \multicolumn{1}{|c|}{ Political Parties } & \multicolumn{1}{c|}{ Manifesto Emphasized } \\
\hline Nepali Congress & $\begin{array}{l}\text { Nepali Congress has prioritised the gender inclusion in all sector of state either } \\
\text { those are political or in other sectors. The party has strongly mentioned in the } \\
\text { election manifesto that the women participation will be minimum 33 percent in } \\
\text { all sector including upper house parliament members, house of representative } \\
\text { members of the state and local level, and will end the gender violence in all form. }\end{array}$ \\
\hline $\begin{array}{l}\text { Nepal Communist } \\
\text { Party (UML) }\end{array}$ & $\begin{array}{l}\text { As Party Election Manifesto Article 52 under the title Inclusion development, } \\
\text { mentioned the 33 percent female participation will be acted as constitution } \\
\text { 2072 in all sectors, including upper house members, house of representatives, } \\
\text { local government (Metropolitan, Sub-metropolitan, Municipality and Rural } \\
\text { Municipality) and in other sectors i.e. socio-economic and development, etc. }\end{array}$ \\
\hline $\begin{array}{l}\text { Rajapa Nepal } \\
\text { The manifesto mentioned that gender inclusion will be in all level of political } \\
\text { opportunities as their right base. They also have emphasized the gender } \\
\text { inclusion in other opportunities i.e. employment, education and participation in } \\
\text { development and other social and political activities. }\end{array}$ \\
$\begin{array}{l}\text { Saghiya Samajbadi Forum } \\
\text { Sanghiya Samajbadi Forum Nepal Election Manifesto 2074, article 5 mentioned that the women will } \\
\text { people, Khas and Arya and other needy people will be bring in the main stream of the national building } \\
\text { process enhancing their fully participation in the political and other development activities beside women. }\end{array}$ \\
\hline
\end{tabular}

Source: Parties Election Manifestos, 2017

There is variation on level of women participation among the countries in the world. In the context of Nepal, women's participation in the parliament is encouragingly increasing.

Table-3: Gender distribution of contested candidates and elected candidates, 2017

\begin{tabular}{|l|c|c|c|c|}
\hline \multirow{2}{*}{ Sex } & \multicolumn{2}{|c|}{ Contested Candidates } & \multicolumn{2}{c|}{ Elected Candidates } \\
\cline { 2 - 5 } & Number & Percent & Number & Percent \\
\hline Male & 90517 & 61.01 & 20705 & 59.04 \\
\hline Female & 57847 & 38.98 & 14329 & 40.96 \\
\hline Total & 148364 & 100.0 & 35034 & 100.0 \\
\hline
\end{tabular}

Source: National Election of Nepal, 2017

The total numbers of contested were 148364 (61.01 percent were male and 38.98 percent female) in local election of 2017 for local government. Among them, 35034 candidates are elected, among the elected members, 59.04 percent are male and 40.96 percent are female. As elected candidates, more than 40 percent are female which are more than allocated (at 
least $33 \%$ female should be included in any section) by the national constitutions 2015 and election manifestos of different political parties and government policies programs.

Table-4: Distribution of elected members by position in Nepal, 2017

\begin{tabular}{|l|c|c|c|c|}
\hline \multicolumn{1}{|c|}{ Positions } & Male \% & Female \% & Total & Number \\
\hline Mayors & 97.24 & 2.76 & 100.0 & 254 \\
Deputy Mayors & 6.18 & 93.82 & 100.0 & 275 \\
Chairman & 97.34 & 2.63 & 100.0 & 418 \\
Vice Chairman & 9.18 & 90.84 & 100.0 & 415 \\
Ward Chairs & 99.28 & 0.78 & 100.0 & 6733 \\
Open members & 98.12 & 1.86 & 100.0 & 12775 \\
Women members & - & 100.0 & 100.0 & 6742 \\
Dalit women members & - & 100.0 & 100.0 & 6568 \\
\hline
\end{tabular}

Source: Election Commission of Nepal, 2017

Majority of male (97.24\%) are elected in Mayor, 97.34 percent in chairman, 99.28 percent in ward chair and 98.12 percent in open members. But higher percent female are elected in reservation quotas (Women and Dalit Women) and second position like 93.82 percent in Deputy Mayor and 90.84 percent in Vice Chairman. However, majority of female are elected in minor post i.e. ward members and deputy post (table 4).

Table-5: Local elected members by province in Nepal, 2017

\begin{tabular}{|c|c|c|c|c|c|c|c|}
\hline \multirow{2}{*}{ S.N. } & \multirow{2}{*}{ Province } & \multicolumn{2}{|c|}{ No of Candidate members } & \multicolumn{5}{|c|}{ Total Elected Members } \\
\cline { 3 - 8 } & & Male \% & Female \% & Total & Male \% & Female \% & Total \\
\hline 1 & Province-1 & 60.85 & 39.15 & 25067 & 58.81 & 41.19 & 6043 \\
\hline 2 & Province -2 & 83.9 & 16.1 & 27248 & 41.15 & 2723 & 6618 \\
\hline 3 & Province -3 & 62.36 & 37.64 & 23613 & 59.27 & 40.73 & 5792 \\
\hline 4 & Province-4 & 60.04 & 39.96 & 12655 & 58.9 & 41.10 & 3934 \\
\hline 5 & Province -5 & 60.88 & 39.11 & 23036 & 58.78 & 41.22 & 5133 \\
\hline 6 & Province -6 & 60.91 & 39.09 & 12402 & 59.97 & 40.03 & 3687 \\
\hline 7 & Province -7 & 59.28 & 40.72 & 14343 & 59.0 & 41.0 & 3834 \\
\hline & Total & 61.01 & 38.98 & 148364 & 59.04 & 40.96 & 35041 \\
\hline
\end{tabular}

Source: Election Commission of Nepal, 2017

While analysing the number of candidates and numbers of elected members for local 
government by province, total 148364 members were candidates for election in all 7 provinces but only $35041(23.62 \%)$ members are elected. As gender, among 90519 male candidates 20689 $(22.86 \%)$ are elected. Similarly, among 57843 female candidate $14352(24.81 \%)$ are elected. As province wise analysis, in province No 1, total numbers of candidates were 25067 . Out of them $6043(24.11 \%)$ are elected and 58.81 percent are male and 41.19 percent are female. In province No. 2, total numbers of candidates are 27248. Out of them 24.29 percent are elected and 58.85 percent are male and 41.15 percent are female. In province No. 3 , total numbers of candidates were 23613. Out of them, 5792 (24.53\%) are elected and 59.27 percent are male and 40.73 percent are female. In province No 4 total number of candidates was 12655 .

Out of them $3934(31.1 \%)$ are elected and 58.9 percent are male and 41.10 percent are female. In province No. 5 total numbers of candidates were 23036. Out of them 5133 $(22.28 \%)$ are elected and 58.78 percent are male and 41.22 percent are female. In province No. 6 total numbers of candidates were 12403. Out of them 3687 (29.73\%) are elected and 59.97 percent are male and 40.03 percent are female. In the province No. 7 total numbers candidates were 14343. Out of them, 3834 (26.73\%) are elected and 59 percent are male and 41 percent are female. Among the elected candidates, gender inclusion in local government is quite high than allocated by Nepal Constitution 2072 as well as election manifesto 2074 of different political parties because, the Nepal Constitution 2072 mentioned that each and every political parties should at least 33 percent women included in their political activities including election too (table 5).

Table-6: Distribution of broad age group of elected local government body by Sex, 2017

\begin{tabular}{|c|c|c|c|c|c|c|c|c|}
\hline Age Group & Mayor & $\begin{array}{c}\text { Deputy } \\
\text { Mayor }\end{array}$ & Chairman & $\begin{array}{c}\text { Vice. } \\
\text { Chairman }\end{array}$ & $\begin{array}{c}\text { Ward } \\
\text { President }\end{array}$ & $\begin{array}{c}\text { Male } \\
\text { Members }\end{array}$ & $\begin{array}{c}\text { Female } \\
\text { Members }\end{array}$ & Total \\
\hline Number & & & & & & & & \\
\hline $21-40$ & 52 & 111 & 112 & 237 & 2036 & 4542 & 6610 & 13700 \\
\hline $41-60$ & 205 & 172 & 293 & 215 & 4057 & 7542 & 6096 & 18584 \\
\hline $\begin{array}{c}61 \text { and } \\
\text { above }\end{array}$ & 36 & 10 & 53 & 8 & 649 & 1399 & 603 & 2757 \\
\hline Total & 293 & 293 & 460 & 460 & 4267 & 13484 & 13309 & 35034 \\
\hline Percent & & & & & & & & \\
\hline $21-40$ & 17.75 & 37.88 & 24.35 & 51.52 & 30.2 & 33.68 & 49.67 & 39.1 \\
\hline $41-60$ & 69.97 & 58.70 & 63.7 & 46.74 & 60.8 & 55.94 & 45.80 & 53.0 \\
\hline $\begin{array}{c}61 \text { and } \\
\text { above }\end{array}$ & 12.29 & 3.41 & 11.52 & 1.74 & 9.0 & 10.38 & 4.53 & 7.9 \\
\hline \begin{tabular}{c} 
Total \\
\hline
\end{tabular} & 100.0 & 100.0 & 100.0 & 100.0 & 100.0 & 100.0 & 100.0 & 100.0 \\
\hline
\end{tabular}

Source: Election Commission of Nepal, 2017 
As a broad aged group of elected Mayor, Deputy Mayor, Chairman, vice chairman, ward president, male members and female members of local government, highest (53\%) percent were of age group 41-60 years and 39.1 percent were of age group 21-40 years and only 7.9 percent were of age group 61 years and above. Similarly, majority (69.97\%) of the elected Mayors are of age group 41-60 years, 58.70 percent are Deputy Mayor, 63.7 percent are Chairman and 60.8 percent are Ward president. But among the Vice Chairman, majority (51.52 \%) are of age group 21-40 years. Likewise, 58.70 percent elected Deputy Mayor are age group 41 years (table 6).

Table-7: Distribution of elected candidates for local government by sex

\begin{tabular}{|l|r|r|r|r|r|r|r|l|l|l|l|l|}
\hline \multirow{2}{*}{$\begin{array}{c}\text { Elected } \\
\text { Candidates }\end{array}$} & \multicolumn{3}{|c|}{ Metropolitan city } & \multicolumn{3}{c|}{ Sub- metropolitan city } & \multicolumn{4}{c|}{ Municipality } & \multicolumn{3}{c|}{$\begin{array}{c}\text { Rural Municipality } \\
\text { (Gaunpalika) }\end{array}$} \\
\cline { 2 - 13 } & $\mathrm{M}$ & $\mathrm{F}$ & Total & $\mathrm{M}$ & $\mathrm{F}$ & Total & $\mathrm{M}$ & $\mathrm{F}$ & Total & $\mathrm{M}$ & $\mathrm{F}$ & Total \\
\hline $\begin{array}{l}\text { Number } \\
\text { of elected } \\
\text { candidates }\end{array}$ & 427 & 440 & 867 & 801 & 490 & 1291 & 9482 & 6587 & 16069 & 10072 & 6925 & 16997 \\
\hline $\begin{array}{l}\text { Percent } \\
\text { of elected } \\
\text { candidates }\end{array}$ & 49.25 & 50.75 & 100.0 & 62.04 & 37.96 & 100.0 & 69.0 & 31.0 & 100.0 & 59.26 & 40.74 & 100.0 \\
\hline
\end{tabular}

Source: Election Commission of Nepal, 2017

While analysing the elected members of local government by local institutions, total numbers of candidates of 867 were elected in metropolitan city out of them 49.25 percent were male and 50.75 percent were female. In the same way, total numbers of elected members are 1291 in sub-metropolitan city of Nepal. Out of them, 62.04 percent are male and 37.96 percent are female. Total number of elected members is 16069 in municipalities of Nepal. Out of them 69 percent are male and 31 percent are female. In Rural Municipality, total numbers of elected candidates are 16997, out of them 59.26 percent are male and 40.74 percent are female. It seems that metropolitan city have female members higher than male members, but in sub-metropolitan and Rural Municipality have more female members than allocated by the national constitutions and election manifestos of political parties but in the municipalities have under the allocated margin. But, the gender inclusion in local government is satisfactory.

\section{Conclusion}

Like in the parliament of Nepal, in all the local levels, women participation is in highly increasing order. In national and local election 2017, almost around 40 and more than 40 percent female from all districts are elected in same ratio throughout the country. The 
gender inclusion by the observation of the following data can be claimed as very high in local government as allocated (33\% minimum) by the Constitution of Nepal 2015 , Election Commission Act, 2017 and election manifestos, 2017 of major political parties.

Overall policies, contemporary policies and acts, development policies and plans of Nepal and international common policies and acts like MDGs, SDGs, Beijing Declaration related to gender inclusion, Cairo Conferences and other relevance, are reviewed to analyse the policies and act status of gender inclusion of national, international and overall global scenario. Researcher found that the act and policies are emphasized in gender inclusion of Nepal as well as in federal structure and local government.

The researcher analysed the different data of elected members like Mayor, Deputy Mayor, Chairman, Deputy Chairman, ward president and members in all local institutions as well as study area of Jhapa and Lalitpur District. It was found that many male candidates were elected in major post like Mayor, Chairman, Ward Chair, but females are elected in only second position i.e. in Deputy Mayor, Vice-Chairman and Ward member. However, gender inclusion in local government seems equal but females are not elected in the major post like Mayor, Chairman and ward chair. So, the researcher tries to find out the reasons why females are not elected in those major posts in the study area.

\section{Acknowledgement}

I would like to thanks to the University Grant Commission, Nepal which provided me $\mathrm{PhD}$ scholarship 2074/75-H \& S-12. I would also like to thanks to the faculty members of Department of Population Studies, Patan Multiple Campus for publishing this article.

\section{References}

Boserup, E. (2011). Women's role in economic development, in Visvanathan, Nalini; Duggan, (edited by Lynn; Nisonoff, Laurie). The women, gender and development reader (2nd ed.). Halifax : London New York New York: Fernwood Publishing Zed Books Ltd.

Central Bureau of Statistics (CBS). (2011). Population census report. Kathmandu: National Planning Commission Secretariat, Ramshah Path, Nepal.

Government of Nepal (GoN) . (2015). Sustainable development goals, 2016/2030: National preliminary report. Kathmandu: National Planning Commission. Singh Durbar, Nepal.

Government of Nepal (GoN) . (2074). Province council member election 2074: Election result book, first inclusive election system. Kathmandu: Election Commission of Nepal, Nepal.

Government of Nepal (GoN) . (2074). Parlialentary council member election 2074: Election result book, first inclusive election system. Kathmandu: Election Commission of Nepal, 
Nepal.

Government of Nepal (GoN). (2074). Local election, 2074. Election Result Book. Province No. 1. Kathmandu: Election Commission of Nepal, Kantipath, Nepal.

Government of Nepal (GoN). (2074). Local election, 2074: Election Result Book. Province No. 2. Kathmandu: .Election Commission of Nepal, Kantipath, Nepal.

Government of Nepal (GoN). (2074). Local lection, 2074: Election Result Book. Province No. 3. Kathmandu: Election Commission of Nepal, Kantipath, Nepal.

Government of Nepal (GoN). (2074). Local election, 2074: Election Result Book. Province No. 4. Kathmandu: Election Commission of Nepal, Kantipath, Nepal.

Government of Nepal (GoN). (2074). Local election, 2074: Election Result Book. Province No. 5. Kathmandu: Election Commission of Nepal, Kantipath, Nepal.

Government of Nepal (GoN). (2074). Local election, 2074: Election Result Book. Province No.6. Kathmandu: Election Commission of Nepal, Kantipath, Nepal.

Government of Nepal (GoN). (2074). Local election, 2074: Election Result Book. Province No. 7. Kathmandu: Election Commission of Nepal, Kantipath, Nepal.

Government of Nepal. (GoN). (2016). Approach paper of $14^{\text {th }}$ three year plan, 2016-2019. National Planning Commission of Nepal. Singh Durbar, Kathmandu.

Government of Nepal (GoN). (2074). Local government election. Kathmandu: Election Commission Nepal, Nepal.

Government of Nepal (GoN). (2007). Interim constitution of Nepal. Singh Durbar, Kathmandu: Government of Nepal, Nepal.

Government of Nepal (GoN). (2073). Political parties related act, 2073. Kathmandu: Council of Ministry, Singh Durbar, Nepal.

International Labor Origination (ILO). (2000). ABC of women worker's rights and Gender equality. Geneva: ILO, Switzerland.

Miller, C., Razavi, S. (1995). From WID to GAD: Conceptual shifts in the women and development discourse, Occasional Paper, No. 1. Geneva. United Nations Research Institute for Social Development. Geneva.

Moser, C. O. N. (1995). Gender planning and development: Theory, practice and training. Oxford University Press, London.

Nepal Communist Party (UML). (2074). Party election manifesto. Kathmandu: UML, Party Office, Dhumbarai, Nepal.

Nepali Congress Party (NCP). (2017). Party election manifestos: Election of upper house parliament members and Local Level. Lalitpur: NCP, Party Office, Nepal.

Sanghiya Samajbadi Forum Nepal (SSFN). (2017). Party manifesto: Election of upper house and 
local level. Balkumari: SSFN, Party Office, and Lalitpur, Nepal

United Nations (UN). (2000). United Nations Millennium Summit: Millennium Development Goals. New York. https://www.un.org/en/events/pastevents/millennium_summit. shtml.

United Nations (UN). (2013). The World declaration on women in local government. The global conference of local elected women. Paris.

United Nations (UN). (1995). Fourth world conference on women, Beijing; adoption of the platform of action. https://www.un.org/en/events/pastevents/pdfs/Beijing_Declaration and_Platform_for_Action.pdf

United Nations Development Program (UNDP). (1995). Human development report 2016: Human development for everyone. New York, United Nations Development Programme, UN Plaza, USA.

United Nations (UN). (2000-2015). Inclusive democracy secures rights. Human development report 2000. New York: United Nations Publication, USA. https://read.un-ilibrary. org/economic-and-social-development/human-development-report-2000_24856282en\#page 17

United Nations Educational Scientific and Cultural Organization (UNESCO). (2017). Social and Human Sciences. Geneva: UNESCO, Switzerland.

United Nations Children Emergency Fund (UNICEF). (2011). Promoting gender equality: An equity-based approach to programming. Specific Reference to Promotion and Entry in Administrative Services. Kathmandu: UNICEF, Nepal. 